Meta

Journal des traducteurs

Translators' Journal

\title{
Translating “Under the Sign of Invention”: Gilberto Gil’s Song Lyric Translation
}

\section{Heloísa Pezza Cintrão}

Volume 54, numéro 4, décembre 2009

URI : https://id.erudit.org/iderudit/038905ar

DOI : https://doi.org/10.7202/038905ar

Aller au sommaire du numéro

Éditeur(s)

Les Presses de l'Université de Montréal

ISSN

0026-0452 (imprimé)

1492-1421 (numérique)

Découvrir la revue

Citer cet article

Cintrão, H. P. (2009). Translating “Under the Sign of Invention”: Gilberto Gil's Song Lyric Translation. Meta, 54(4), 813-832. https://doi.org/10.7202/038905ar
Résumé de l'article

La traduction de chansons partage avec la traduction subordonnée les mêmes difficultés et, avec la traduction poétique, les mêmes impossibilités. Dans sa version de "I just called to say I love you" de Stevie Wonder, Gilberto Gil fait appel à deux procédés : d'une part, le découpage de larges champs sémantiques comme unités de traduction, et d'autre part, le choix délibéré d'une adaptation culturelle de la traduction. La manière dont Gilberto Gil traite les difficultés de la traduction de la chanson n'est pas sans évoquer les principes de la transcréation de Haroldo de Campos. 


\title{
Translating "Under the Sign of Invention": Gilberto Gil's Song Lyric Translation
}

\author{
HeLOÍSA PEZZA CINTRÃo \\ Universidade de São Paulo, São Paulo, Brazil \\ helocint@usp.br
}

\begin{abstract}
RÉSUMÉ
La traduction de chansons partage avec la traduction subordonnée les mêmes difficultés et, avec la traduction poétique, les mêmes impossibilités. Dans sa version de "I just called to say I love you" de Stevie Wonder, Gilberto Gil fait appel à deux procédés: d'une part, le découpage de larges champs sémantiques comme unités de traduction, et d'autre part, le choix délibéré d'une adaptation culturelle de la traduction. La manière dont Gilberto Gil traite les difficultés de la traduction de la chanson n'est pas sans évoquer les principes de la transcréation de Haroldo de Campos.
\end{abstract}

\begin{abstract}
The translation of song lyrics shares in the difficulties of constrained translation, as well as in the impossibilities of poetic translation. In Gilberto Gil's adaptation of the song "I just called to say I love you" by Stevie Wonder, two translation procedures stand out: (1) to take broad semantic fields as translation units, and (2) to opt for cultural adaptation in terms of the translation's poles of domesticating/foreignizing. The way Gil faces up to the challenges of the translation of the song is consistent with Haroldo de Campos ideas on transcreation.
\end{abstract}

\section{MOTS-CLÉS/KEYWORDS}

chanson, traduction subordonnée, transcréation, Gilberto Gil, Haroldo de Campos song, constrained translation, transcreation, Gilberto Gil, Haroldo de Campos

\section{A functional issue in song translation}

If we search, at random, the website of a Brazilian radio station, and take a translation into Portuguese of the lyrics of "I just called to say I love you" by Stevie Wonder, ${ }^{1}$ which is intended to be spoken by a radio announcer, as in simultaneous interpretation mode, we will note striking differences between the translation and the lyrics devised in 1985 by Gilberto Gil, ${ }^{2}$ as a translation of the same song, but which is meant to be sung. It cannot be said in a vacuum that one of them is more precise or desirable than the other, in comparative terms. The fact of having been conceived to accomplish quite different functions makes them not directly comparable in terms of quality, though they are grounded on the same source text. In this case, it is only possible to consider the appropriateness of each one in light of their different purposes, respectively: (1) to enable a Brazilian radio listener who does not understand English to receive information about what the English words and sentences in Wonder's lyrics mean, linearly and literally; and (2) to allow the song to be understood or sung by somebody who masters Portuguese well, providing an aesthetic pleasure similar to that which Wonder's song is able to produce when listened to or sung by somebody who masters English well. 
Some of the still few studies on vocal translation point to the consistency of functionalist proposals and to their capacity of covering diverse and complex translation phenomena. With reference to the legitimacy of varied translation methods according to the skopos (or aim), for instance, Peter Low (2003) shows that Art Songs have been translated under various purposes, which could be organized into five functions, each of which is associated with a more suitable translation strategy. Some of the possible relations between functions and strategies to Art Songs translation are the following: (1) a translation for the singer to use as a reference while rehearsing the song could be appropriately presented in print parallel format or in interlinear format, as a gloss translation; (2) a translation devised to be read in a concert programme could be provided as a clear translation of the contextual meaning, in prose format or as unrhymed free verses, so that it could be "reader-friendly" and "digested in a relatively limited time"; (3) in a singable translation (not usual in the field of Art Songs), the translator is subjected to "huge constraints imposed by the pre-existing music," and cannot ignore "the rhythms, the note values, the phrasings or the stresses of the music" (Low 2003: 103-104). In another text, Low (2005: 186) considers that, in the field of song translation, "the most difficult skopos is the singable TT, on account of its many constraints."

Reiss and Vermeer (1984/1996: 121) define a communicative translation (which is considered to be a translation in its strict sense) as "information concerning a communicative offer by means of 'imitating' the informative offer of the source text with the resources of the target language and culture" (our translation from Spanish). They add that communicative translation is characterized by the maintenance of a similar function between the source text (ST) and the target text (TT). According to this view, only a translation meant to be sung should be considered as a translation in the strictest sense of the term, since it has the property of maintaining the most characteristic function of the lyrics in the target context as it had in the source context. But, oddly, song translation is a case in which communicative translation needs to consider formal features intensely, due to the constraints imposed by the melody, and requires, therefore, an intensive use of creative strategies, which characterize more properly Reiss' creative translation.

In this hybrid of communicative and creative translation, to what degree would it be necessary to consider semantic components - mainly the linear sequence of superficial meanings - as equivalence parameters (the parameters of a link between two informative offers and of ST imitation) so that we can properly speak of translation, in the case of a song? Is it really possible to speak of translation in this case?

\section{Song translation as constrained translation}

Song translation is a type of constrained translation. Titford (1982) introduces the term constrained translation when writing on the limits imposed on the translation of the verbal text by space and synchronicity with the visual scenes in subtitling. Later on, Mayoral, Kelly and Gallardo (1988: 356) extended the use of that term to all types of translation in which "the text is influenced by the concurrence of other communication systems or elements such as image, music, etc." On that kind of translation, say the authors, "the non-linguistic elements of the message not only constitute part of the meaning but also, on occasions, impose their own laws and 
conditions on the text" (Mayoral, Kelly and Gallardo 1988: 366). In subtitling, dubbing, comic strip translation, as well as in other types of constrained translation, the non-linguistic systems normally cannot be modified, the translator "can only work with the text and all the necessary adjustments must be made in relation to the text" (Mayoral, Kelly and Gallardo 1988: 363).

Hurtado (2001: 92) points out that, considering constrained translation as a whole, song lyrics are one of the least frequently translated types, and also the least studied type. Considering the rarely studied "vocal translation"- libretti, musical comedy, art songs, folk songs, etc. (Gorlée 2005: 7) -, studies on the subgenre of popular song translations are especially rare, despite the great volume of song translations in this case:

Popular songs are important mass media products through which cultures are articulated and hence communicated to people of different linguistic, historical and cultural backgrounds. Notwithstanding their presence, popular songs have largely been neglected in translation studies (Kaindl 2005: 235).

Some of the special difficulties of song translation are explained by Hurtado (2001: 92) as follows: "the linguistic and musical codes are blended, and, therefore, the translator needs to subordinate the translation of the linguistic code to the musical rhythm and to the tonal groups, and establish a synchrony between the text and the music" (our translation).

That difficulty for the translator has its counterpart in the study of this type of translation. In the view of Mayoral, Kelly and Gallardo (1988), all kinds of constrained translation require an approach that cannot be exclusively linguistic, but should be semiotic, taking into account the presence of non-linguistic codes.

\section{Song translation as poetry translation}

Even if we put aside the presence of the musical code, we will have to consider that song translation has difficulties due to its own textual structure. Song lyrics are often shaped with resources similar to those of a poem. The translation of poetry has its own restrictions, which are not so far removed from those that characterize constrained translation. ${ }^{3}$

In poetry, various types of sonorous reiteration such as rhyme, metre, rhythm and parallelism can be seen as variations of a common principle: the projection of similarity along the axis of selection (paradigmatic) over the axis of combination (syntagmatic), according to Roman Jakobson (1960/2001). The resulting interplay of sounds produces an experience of verbal flow comparable to the experience of musical tempo.

By definition, the poetic or aesthetic function of language makes use of the sonorous (or iconic) materiality of the utterance. Moreover, the poetic text projects formal similarities over meanings. Jakobson holds that poetry's inherent untranslatability is due mainly to the fact that poetry makes use of the form of language itself, within which it searches for new meanings. When the aesthetic function plays a dominant role, over and above the other functions, this partially nullifies the principle of the signifier's arbitrariness. The result, in the words of Jakobson (1959/1966: 238), is that "[...] poetry, by definition, is untranslatable. Only creative transposition is possible." 


\section{The issue of faithfulness in song translation}

Reiss holds that, for any kind of translation, faithfulness is a multifaceted issue, since equivalence itself is a polyfaceted concept:

[...] a text does not only have a content, not just a "sense" or a content-in-situation [...]; it also comprises form and effect. If the translation changes these two aspects substantially, we cannot talk about equality of values in general, that is, we cannot talk about equivalence between the source text and the target text anymore (our translation from Spanish; Reiss and Vermeer 1984/1996: 113).

The interplay between form, sense and effect is complex even in texts that only deal with the linguistic code. One of the challenges when studying song translation is how to consider the faithfulness to the verbal text meaning in a translation that jointly deals with verbal forms, musical forms and their respective and combined effects.

In a study on German songs, Haupt (1957: 228) states that there are two types of popular lyric-song translations: (1) "those which completely change the original text"; and (2) "others which try to reproduce the source text and only make minimal changes necessitated by musical constraints" (quoted in Kaindl 2005: 237). Observation shows that these two types proposed by Haupt are not two categories with clear-cut boundaries between them, but mainly two poles of a continuum along which there may be various degrees.

Low (2005) believes that the evaluation of a song translation should be done according to the balance the translator achieves between five major criteria: singability, sense, naturalness, rhythm and rhyme. Attaining an optimal compromise between those five criteria requires a sixth element: flexibility to negotiate losses of accuracy in each of them in order to gain a best overall balance as a whole. Within this proposal, the importance of the meaning of the verbal text is considered as follows: "in the normal translating of informative texts, for example, semantic accuracy is paramount; but the constraints of song-translating necessarily mean some stretching or manipulation of sense" (Low 2005: 194). To Low, it is necessary to work on sense correspondence with a broader margin for flexibility in this kind of translation than for other kinds of texts. But, in his opinion, the sense correspondence with the source text still deserves great importance, otherwise, it would not be possible to talk about translation.

I note in passing that some people ignore sense altogether: they take a foreign song-tune and devise for it a set of TL words which match the music very well but bear no semantic relation with the ST. While this may at times be good and appropriate, it is not translating, because none of the original verbal meaning is transmitted. Such practices have no place in discussions of translation (Low 2005: 194).

Talking about translation in general, Halliday (2000) argues that an essential requirement so that a text can be assessed as a good translation is for it to be a translation. Hence, the equivalence in the semantic level tends to receive the highest value in translation in general, when considering hierarchies of equivalence among different linguistic and contextual strata. That is to say, to match the sense of a ST is an essential parameter to assess translation quality, and it precedes any other, simply because it seems to constitute the proper definition of translation. 
In that issue lies one of the challenges for the general theory of translation: is it possible to determine any limit separating translation, in the proper sense, from adaptation? To what degree of accuracy or extent is it necessary to match the senses and the shape of a pre-existing text to accomplish this first essential requirement that defines a genuine translation? Would these limits have any specificity in the field of song translation, or constrained translation in general? It is significant that, in Brazilian Portuguese, song translation is more frequently referred to by the word versão, which in this context means the same as adaptation.

\section{The manipulation of meanings in song translation}

Kaindl (2005) analyses cases of pop song translations that show only a tangential connection with the source lyrics, without denying a place in Translation Studies for these more extreme cases. He finds strong tendencies towards acculturation, domestication and globalization within the scope of popular and pop song translation, and he inquires about the reasons behind the profound manipulation of the meanings and even of the musical styles, vocal interpretations and musical arrangements that he notices in his case studies.

One thing that certainly might influence the degree of manipulation of the source text in a song translation is the fact that, according to "the relative weight and importance given to either element of the double symbiotic construct [poetic and musical texts]," there are more logocentric or more musicocentric attitudes towards vocal translation:

While logocentrism, a view defending the general dominance of the word in vocal music, may be called by the aphorism prima le parole e poi la musica, musicocentrism is expressed in its opposite, prima la musica e poi le parole. Musicocentrism is, for all practical purposes, a wordless approach. Not surprisingly, strict logocentrism is a rather weak position within the study of vocal music (Gorlée 2005: 8).

Apart from the differentiation between more logocentric and more musicocentric views in song translation, it is possible to enumerate other variables which can influence the choice for a higher or lower semantical approximation between TT and ST when translating a song: for example, the specific linguistic pair (typologically closer or more distant languages), the "poetic status" of certain song lyrics (higher or lower degree of poeticity perceived in a song lyric, or poetic authority assigned to its author), the personal preferences of the translator for certain translation strategies due to his/her own conceptions of translation, or also the reasons why an artist chooses specific songs to be translated.

When considering acculturations, domestications, globalizations and massive changes of content in pop song translations, Kaindl (2005: 237) attributes a special importance to some possible reasons pointed out by Worbs (1963). Firstly, there may be a strong influence of the image of the singer "who has to fulfill certain expectations of his audience": the style and the content of a translated song are shaped so that it can suit the rest of the singer's repertoire. A second reason could be the "specific mentality of a nation": the meanings of popular songs are heavily dependent on the social-cultural background (Worbs 1963, quoted in Kaindl 2005: 237).

The background-sensitiveness which characterizes popular songs and their translation can probably be greatly assigned to the following factors: the character 
of entertainment of songs; the ephemerality and speed of the auditory medium, which calls for less concentration and more immediate attention (Golomb 2005: 139-140); the characteristics of "firstness" of the music (Gorlée 2005: 50), a more abstractly aesthetical and emotive component of meaning, which is more vaguely sensorialauditory than rational or conceptual.

"Não chore mais" (Don't cry anymore ${ }^{4}$ ) - an adaptation by Gil for "No woman, no cry" by Vincent Ford - can shed some light on these interplays. In the first stanza of Ford's lyrics there is a mention of "the government yard in Trenchtown." Gil replaces it with a new setting, "a grama do Aterro" (the grass of the Aterro [do Flamengo]), in the Brazilian city of Rio de Janeiro, thus using a deliberate procedure of domestication or cultural analogy. Gil explains that he intended to do a "transposition of a Jamaican scene to a Brazilian scene as similar as possible in its physical, urban and cultural aspects" (Gil, in Rennó 2003: 243, our translation). While dealing with a popular song, Gil probably saw that his translation required an immediate communicative appeal as well as the potential for bringing about identification and empathy on the part of the Brazilian audience. This treatment was successful: "Não chore mais" was one of Gil's greatest hits.

Other procedures used in that same translation also illustrate that the adaptation to the image and to the repertoire of the singer is an important reason for the manipulation of the meanings in lyric-song translations, in the field of popular music. When explaining why he translated the verse "you can't forget your past" by "melhor é deixar pra trás" (literally, it's better to leave it behind, meaning "it's better to forget it"), Gil shows awareness of having adapted the song lyric to his own world vision:

There is a certain interpretive liberty there. [...] I was referring to a period that was ending in Brazil [the translation was made during the military dictatorship], and I say: "Let's erase these memories. The past is in debt to us, but let's give a credit to the future." This is a typical position of my internal ideology, of my optimism, of my taste for conciliation, of the tolerant trait of my personality (Gil, in Rennó 2003: 244, our translation).

When it comes to popular song translation in Brazil in the last, say, 40 years, it is not difficult to identify the two overall types proposed by Haupt (1957). Actually, in a pole of popular song translation in Brazil, we can talk about a norm that allows a huge amount of freedom in the transposition of the meanings of lyrics, and we can find many cases in which an artist who translated a popular song seems to feel totally free to overlay practically any lyrics at all to the original melody. Maybe it is because, as pointed out by the reviewer of the first version of this article, "people who translate songs do not usually regard themselves as 'translators,' nor do they regard their practice as one of translation. These people are more often than not song writers and consider their work as adaptation/recreation."

An example of these extreme cases is Gil himself, in his song "When the wind blows" (1982), which is an adaptation to English (a foreign language to Gil) of one of his own songs written originally in Portuguese and entitled "Deixar você" (1981). The lyrics of the original song "Deixar você" (literally, To leave you as well as To let you) infer a situation of the imminent separation of a couple, and is structured as arguments in favour of a reconciliation. By contrast, the English lyrics, composed in partnership with Ralph MacDonald and William Eaton, "When the wind blows," take the image of the wind blowing toward different cardinal points at different 
moments of the lyrics, as a metaphor for life's bitter or sweet moments. The procedure of completely overlaying another text to an original song of his own authorship coincides, in that case, with the fact that "Deixar você" is a song about which Gil shows a musicocentric view, since he does not seem to attribute much importance to its lyrics:

"Deixar você" [...] wasn't based on any actual person. The character of its lyrics is invented and arose from a decision such as: "I'll write a song." Actually, "Deixar você" was composed in order to imitate Djavan; I wanted to create a song that had to do with the way I thought Djavan composed his songs. I had been doing some melodic-harmonic sequences which were, in my view, similar to those he does, with some features of his style, and then, after finishing the music, I thought: "Well, what am I going to do with that?" Then I wrote the verses, in which I wasn't dealing with a real situation about which I really wanted to elaborate any reflection (Gil, in Rennó 2003: 302, our translation).

It seems that the complexity of vocal translation cannot be easily organized in terms of variables: even when considering only one country (Brazil), the same moment (contemporary), the same genre (popular songs) and the same author, we see in the case of Gil that there can be enormous variations of procedures in song translation. The same author can adopt, for instance, a logocentristic or a musicocentristic position at different moments.

\section{Gilberto Gil as a song translator}

Before analysing the adaptation by Gil for the song of Stevie Wonder, it will be useful to locate that translation - done in 1985 - within the whole work of Gil along the forty years covered by the compilation Gil, todas as letras, (Gil, all lyrics) by Carlos Rennó, from Gil's first lyrics, composed in 1962, to the moment the book was finished in 2002.

Rennó divides Gil's work into eight major periods: (1) his first songs before the avant-garde movement of Tropicália (1962-6); (2) from Tropicália till Gil's departure from Brazil due to problems with the military dictatorship (1967-9); (3) his songs during the two years of exile in London and the three years after his return to Brazil (1970-4); (4) the period of his two first works of the conceptual trilogy of albums with the prefix re-(Refazenda, Refavela, and Realce) - also the period of the formation of the group Doces Bárbaros, with the "new-baianos" Maria Bethânia, Gal Costa, and Caetano Veloso (1975-8); (5) Gil's most pop phase, started with the recording of the album Realce (1979-83); (6) the remaining production of the 80's (1984-9); (7) the 90's; (8) the first years of the $21^{\text {st }}$ century (Rennó 2003: 11).

During most of these periods, apart from tunes and lyrics for popular songs in his mother tongue (Portuguese), Gil composed lyrics originally in English and French (foreign languages to him), translated songs from Portuguese to English (mostly source lyrics of his own authorship) and translated songs from English to Portuguese (mostly someone else's songs, but also two of his own compositions with original lyrics in English).

Surprisingly, his interlinguistic activity did not start with translations to his mother tongue, but with the composition of lyrics originally in English and with lyric translations from Portuguese to English. That started to take place in the third phase 
of his career and was clearly motivated by his exile in London (1970-1971). The songs he composed originally in English during that period - alone or in partnership with Caetano Veloso or Jorge Mautner - were mostly prepared for the album he recorded in exile.

The translations into Portuguese of someone else's songs began only some years after he returned to Brazil. They are enumerated in chronological order as follows: (1) "De leve," 1977 ("Get Back," John Lennon and Paul McCartney, recorded by the Beatles, 1969); (2) "Não chore mais," 1977 ("No woman, no cry," Vincent Ford, 1974, recorded by Bob Marley, 1974 and 1975); (3) "Sargento Pimenta e a Solidão,"1981 ("Sgt. Pepper's Lonely Hearts Club Band," John Lennon and Paul McCartney, recorded by the Beatles, 1967); (4) "Só chamei porque te amo," 1985 ("I just called to say I love you," Stevie Wonder, 1984); (5) “Mande-me algo," 1997 (“Send me some lovin,” Lloyd Price and John Marascalco, recorded by Little Richard, 1957; by Stevie Wonder, 1967; by John Lennon, partially, 1975); (6) "Eleve-se alto ao céu," 2001 ("Lively up yourself," 1974, Bob Marley); (7) “Kaya n'gan daya," 2001 (“Kaya," 1978, Bob Marley); (8) “Tempo só," 2001 ("Time will tell," 1978, Bob Marley). This list can be complemented by the translations he did of two of his own lyrics composed originally in English: (1) "Vamos fugir," 1984 ("Gimme your love," reggae of 1984, the first recording of which was made in Jamaica); (2) “Mesa tennis mesa," 2002 (“Table tennis table," 2001, a tribute to Bob Marley).

The above enumeration suggests at least two criteria that guided Gil while choosing songs to be translated. (1) One of them seems to be an interest in foreign contemporary rhythms such as rock, funk, pop and, very especially, in Bob Marley's reggae. Actually, some noteworthy features of Gil's work in the field of popular music is his versatility to compose in a wide range of styles and rhythms, and his concern with including in his repertoire, representative songs and elements of folk music from different parts of Brazil as much as songs that mingle modern international styles, especially those marked by African rhythmic heritage, as in the case of the musical styles mentioned above. His choice of songs clearly shows the influence of the Beatles and of Bob Marley on him. (2) Secondly, it is quite clear that almost all of his choices are related to the work of black artists. In fact, an overall view of the lyrics assembled by Rennó (2003) shows the issues of black people and African cultural heritage as important themes and motives for numerous compositions. Here again, we can see clearly to what extent translated songs fit in the repertoire of the artist.

In his translations to Portuguese, Gil pays careful attention to cultural analogies. The song "Sgt. Pepper's" impresses him mainly because of the theme of the bands, which he associates with his childhood, in the village of Ituaçu, in the backwoods of Bahia:

A band is where music begins for me: my fascination with music arose in my childhood from my fascination with a band. One of the important points of my history were early mornings with the musicians of the brass band of Ituaçu - the "Lira Ituaçuense" -, in uniform, playing around the streets. [...] That's why I was delighted by "Sgt. Pepper's Lonely Hearts Club Band": it was [...] like remembering things that I'd lived in my village. I thought the world of bands was wonderful. [...]. "Sgt. Pepper's" was fully emblematic of this world. This song [...] moves all of us, musicians; and especially me: for me, Pepper, a musician of a bandstand brass band, was just like Sinésio Fogueteiro, from Ituaçu (Gil, in Rennó 2003: 297, our translation). 
The above comments reveal to what extent very subjective factors of identification can guide the choice of one or another song to be translated, within the overall context of the biography and of the whole work of a musician.

The translations made by Gil from Portuguese to English will not be listed here. It will only be mentioned that they can be divided into translations of songs of his own authorship (in most cases) and translations of someone else's songs. It is also worth pointing out that his translations to Portuguese (mother tongue) of songs of other authors (8 song translations) are less numerous than the translations of his own songs to a foreign language (11 song translations).

Stevie Wonder's releases "I just called to say I love you" in 1984, soon after what was considered the most pop phase of Gil's career (1979 to 1983). In 1985, Gil writes his translation, released in 1987. For the subsequent analysis, an alignment of Stevie Wonder's lyrics and of its adaptation by Gil is provided in appendices, including a back translation.

\section{Under the sign of faithfulness: the translation of the chorus}

Having in mind the two types of song translations proposed by Haupt (1957), a brief overview of the alignment of Wonder's and Gil's lyrics instantly shows that: (1) the chorus translation is a typical example of the kind of song translation "which tries to reproduce the source text and only makes minimal changes, which are necessary due to musical constraints" (Haupt 1957, quoted in Kaindl 2005: 237); (2) except for the chorus, there is a lack of coincidences between the surface meanings of the parallel verses.

The translation of the chorus shows one of the highest degrees of faithfulness to the linear surface meanings that it would be possible to attain without losing naturalness, if we consider the distance between Portuguese and English and the typical need of song translation to match the verbal text with the original tune. The semantic and syntactic manipulation are minimal in the first verse of the chorus - "I just called to say I love you" -, translated as "Só chamei porque te amo" ("I just called because I love you," in back translation). They are limited to the exclusion of the verb to say, which remains implicit, however, in the very dialogue structure of the chorus. The conjunction "porque" (because) corresponds adequately to the purpose of the semantic relation represented by "to" in "to say I love you." Cause and purpose are actually quite close semantic relations.

Nevertheless, a lexical choice attracts attention because it produces an apparently unnecessary lack of accuracy. The Collins Cobuild Dictionary (2003: 194) gives several definitions of the verb to call, including the following: "if you call someone, you ask them to come to you by shouting to them" and "if you call someone you telephone them" (my emphasis). In Wonder's lyrics, "called" has the meaning of the second quoted definition, and this is strengthened in the song video clip with images of Stevie Wonder singing on the telephone. That sense of talking on the phone, however, is usually expressed in Brazilian Portuguese by the word "ligar," while the verb "chamar" is usually interpreted as "ask someone to come to you," even though, with respect to the noun forms, the words "chamada telefônica" or "ligação telefônica" both have a high frequency of use. Considering only the metre and the number of notes in the original melody, it would have been perfectly possible to translate "só 
liguei porque te amo." The preference for "chamei" probably has to do with its vowel /a/, which corresponds better to the open sonorities of "just" and "call" in the original verse, if compared to the closed sound of the Portuguese vowel /i/ for "liguei."

Commenting on two of his song translations (in Rennó 2003: 469), Gil shows his concern for the use of Portuguese words that refer to the sonority of the source lyrics. In the case of the adaptation "Eleve-se alto ao céu" (2001) - for "Lively up yourself" by Bob Marley -, the concern for maintaining part of the sonority of the original words is what leads Gil to put "ao céu" (to the sky) in the melodic passage which corresponds to the word "yourself." Gil translates the key-sentence of the chorus (also the title of the song) - "lively up yourself" - as "(e)leve-se alto ao céu," literally "lift yourself high to the sky" or "lead yourself high to the sky." The meaning of "yourself" is retrieved in another melodic passage, by the reflexive pronoun "-se," in "eleve-se." The consonant sounds of /1/ and /v/ appear both in "lively" and "(e)leve-se." When commenting this case and the translation of the title (and chorus) of "No woman, no cry" -, Gil clearly gives importance to phonetic equivalences:

This is a resource I like to use in song translations, mainly in emblematic songs, when the sonority of key-terms has already become universal: everybody listens to that sound internally; the sound of the words is deeply infused in the memory of that song. In "Não chore mais," the adaptation of "No woman, no cry," I applied that, using "mais" [more] in the place of "cry," to explore their phonic similarity [...] in the chorus [...]. In "Lively up yourself," it took me months to find the solution for the initial verse [...] It occurred to me "leve-se/eleve-se," the idea of using that double option [...] By doing that, I tried to bring the sounds closer and to cover two meanings: that of "lift up," by "eleve-se," and that of weight, by "leve-se" [as a pun on the adjective "leve" (light), instead of the verb "levar" (to take; to lead), it could mean something like "lighten up"], a form with one more syllable. To finalize, at the end of the verse I utilize "céu" [sky] as a sound correspondence for "self," in "yourself." The recreation of that sentence is maybe the best solution I have ever found for an adaptation of a song lyric (Gil, in Rennó 2003: 469, our translation).

In both cases mentioned by Gil, the sentences were core verses of the chorus as well as the title of the song, just like in the case of "I just called to say I love you." The opening of /a/ for "chamei" could have been, thus, the reason why Gil opted for a lower degree of accuracy, lower than what he could have obtained using "liguei." Here, he probably preferred to lose accuracy in semantic equivalence in order to score highly in the phonic equivalence. Gil seems to use this strategy particularly in key passages such as core verses of the chorus and in titles.

Wonder's lyrics has slight vowel rhymes between "care" and "heart," in the verses that alternate with the repetitions of the key sentence "I just called to say I love you." Gil retrieves the word "coração" (heart) in the position of a final rhyme, in the last chorus verse, and devises a relatively close semantic translation of that verse, circumscribing meaning manipulation to changes needed to match the text to the original tune: "and I mean it from the bottom of my heart" receives the translation "lá bem fundo, fundo do meu coração" (something like There in the very bottom, bottom of my heart, in back translation). A greater manipulation of meaning can be noticed in the translation of the second verse of the chorus - "I just called to say how much I care" - by "só chamei porque é grande a paixão" (a literal back translation: because it's big this passion). It can be due to the choice of the word "paixão" to rhyme with 
“coração." Despite certain lack of word-by-word correspondence between the source and target text in that verse, clear common denominators can be found in the expression of affection ("I care" and "a paixão") characterized by great intensity ("how much" and "é grande").

A clear similarity in terms of poetic macrostructure can be seen in the chorus alignment:

TABLE 1

Source and target chorus alignment
A: I just called to say I love you
A: Só chamei porque te amo
B: I just called to say how much I care
B: Só chamei porque é grande a paixão
C: I just called to say I love you
C: Só chamei porque te amo
D: And I mean it from the bottom of my heart
D: Lá bem fundo fundo do meu coração

The sentence that is the title of the song is fully repeated in the verses A and C, both in the original chorus and in its translation. Other points in common are the following: the initial part of verses A/C is repeated in B ("I just called" - "Só chamei"), forming a parallelism between $\mathrm{A} / \mathrm{C}$ and $\mathrm{B}$; verse $\mathrm{D}$ does not maintain that parallelism with the three initial verses; verses $\mathrm{B}$ and $\mathrm{D}$ have a final rhyme; verses $\mathrm{A}$ and $\mathrm{C}$ have a metre of 8 syllables and are sung in 8 notes; the melody is almost identical for A and C; verse B has 9 syllables and is sung throughout the same 9 notes; verse D is the longest one, with 11 syllables (but it is sung with slight rhythmic modifications in the translation). In short, Gil's chorus is an almost literal translation of Wonder's, and any instance of unfaithfulness on its part can easily be attributed to the formal requirements of rhyme, metre, sonority and number of notes of the melody.

The high degree of faithfulness in this chorus translation is coherent with its thematic centrality. The title sentence which repeats itself twice contains the thematic core of Wonder's love song: someone making a telephone call to get in touch with someone else and to say how he/she feels about this person, without using any excuse, but in a sincere and straightforward way. In the rest of the lyrics, Wonder shapes a poetic imagery for that leitmotif in numerous variations.

\section{Stevie Wonder in Gilberto Gil's Brazil: no Halloween}

With the exception of the 4 chorus verses, there is an almost absolute lack of correspondence between the surface meanings of each of Wonder's verses and its melodically corresponding verse in Gil's lyrics. The total number of verses is 20, the same in the ST and in the TT. Subtracting the 4 chorus verses, we have 16. In the 9 verses marked with an asterisk in the alignment (verses 2, 3, 4, 5, 7, 15, 16, 19 and 20), the lyrics by Wonder and Gil do not show any surface meaning link between each other (more than 56\% of the total verses). There are only 3 (less than 19\%) verses that have some coincidence of meaning (verses 1,8 and 14), in which that coincidence is just partial, and was underlined in the alignment (only the words or fragments that are similar between the original verse and its corresponding verse in the translation). Being especially optimistic, it would be possible to see subtle points of tangency between the meanings of the 3 remaining verses (verses 6, 13 and 17), less than 19\% 
of the total (in these cases, the words or fragments that could suggest some surface meaning contact between corresponding verses appear with a dotted line in the alignment). Adding these last 3 verses that have too much of a conjectural semantic link and those without any surface meaning in common, we have a total of 12 verses $(75 \%)$ that do not have any common surface meaning with ST.

Compensation is important and frequent in poetry and song translations, as a strategy to face the formal constraints to which they are submitted. Even assuming that the surface meanings of the ST verses could have been conveyed to noncorresponding verses in the TT, the numbers above do not change significantly. We can only add some considerable similarities between verse 3 (Wonder) and verses 7-8 (Gil); verse 4 (Wonder) and verse 3 plus verse 5 (Gil).

But considering thematic levels, deeper and more abstract than the surface meanings of the verses, it is possible to see an important semantic coincidence: most of the verses of the ST and TT lyrics are variations on the theme that there are no extraordinary events taking place, and that, from this point of view, there is no special reason for calling. The only verses that depart from this pattern are the verses 7 , 8, 19 and 20 by Wonder and the verse 20 by Gil. All the others embody this same idea. But the mere fact that two texts have an essential theme in common is not enough to define the relation between them as one of translation.

In order to formulate the close connections that can be intuitively realized between these two lyrics, an important path is to remember Reiss' statement according to which a text is not only composed of content, but also of forms and effects. The close similarity between the two lyrics in terms of their macro-structural shape is clear even at first sight.

The global frame of the source lyrics supposes that the "I" that talks addresses, on the telephone, a specific "you" with whom he is in love. In his speech, he juxtaposes sentences - mostly negative clauses - in which he comments on the thematic idea. Gil's text coincides with Wonder's in its parallelistic structure, with most verses beginning with a negative particle. As in the ST, negative forms are applied to special days or extraordinary events that could have been used as excuses for the telephone call referred to in the chorus. In Wonder's lyrics, the initial negative particle is always the word "no," with a single variation: "not even" (verse 16). In Gil's lyrics, there are 7 different negative particles of Portuguese opening the verses: "não,"“nem,"“nenhum” and its feminine form "nenhuma," "nada," "ninguém," "nem mesmo." Probably Gil got excited by the inventive parallelistic structure of Wonder's song and decided to list Portuguese negative particles to alternate them in a balanced way throughout his lyrics.

In Wonder's lyrics, the content of the negations in the verses can be divided into two clear semantic fields: one that contains special/festive dates, and another that involves months or seasons of the year together with their corresponding natural phenomena. These latter are sometimes associated with certain romantic clichés, such as the moon, marriage, flowers... (A map of the semantic fields' distribution throughout Stevie Wonder's verses is provided in Appendix 2.)

These two semantic fields are interconnected in Wonder's lyrics due to a chronological sequence that covers the seasonal cycle of an entire year, beginning with the reference to the New Year celebrations (January) and closing with the mention of Christmas (December). In Wonder's lyrics, all the months of the year are represented, 
in an accurate chronological order, either by an overt reference ("no April rain") or indirectly (printed in italics in Appendix 2) through the reference to a holiday ("no Halloween" indicating October; "no chocolate covered candy hearts to give away" referring metonymically to the American Valentine's Day, in February); or also by a reference to the beginning of a season ("first of spring" representing March). Thus, the course of time is embodied by natural and social phenomena, and an entire year parades visually, month by month, as a film before our... ears. This structuring principle is more subtly suggested in Gil's lyrics, but also exists there: the lyrics begin with an overt mention of Christmas and New Year's (December and January), passing through, in chronological order, by Carnival (February) and Saint John's Festival (June). No month is directly named. (See the semantic fields' distribution for Gilberto Gil's verses in Appendix 3.)

Gil's also maintains the semantic field of the holidays/special days and also organizes them in chronological order along the period of a year, but adapts them culturally. Thus, the "chocolate covered candy hearts," a metonymy for the American Valentine's Day, and "Halloween" are transformed into the "balão no céu" (balloon in the sky), a metonymy for the June festivals of St. John's, St. Peter's, or of St. Anthony's wedding-related festival, or into Carnival, which, like Halloween, is a festival with masks and costumes, including those of witches, vampires, monsters, and devils. Although not appearing in the same melodic phrases as the Americans', the Brazilian holidays of Gil's lyrics share with them an easily recognizable link of semantic and cultural correspondence. It indicates that applying a cultural filter (in the sense of House 1977/1981) was an important translation procedure used by Gil, and that it was applied not only to one or two translation units, but to an entire semantic field. Some comments Gil makes on this song translation show that conscious intention: "[...] the translation parallels, tries to freely convey to Brazilian equivalents the festive American occasions referred to in the original [...]" (Gil, in Rennó 2003: 361). Important changes can be noticed in the musical arrangement Gil does for his adaptation of Wonder's pop song. In his recording, Gil only uses voice and one acoustic guitar, playing it in a slow ballad rhythm. Maybe, we can also see a kind of domestication in that.

Besides, Gil almost totally omits the semantic-conceptual field of the seasons related to well-demarked seasonal natural phenomena, which do not occur in the tropical and subtropical climates of Brazil as they do in temperate ones (see Appendix 3). From this point of view, we can see, in the case of this omitted semantic field, a procedure of domestication.

A new field compensates the omission of the seasons, which has an important presence in the original. The new field is that of exceptional occurrences, including things that would make it to newspaper coverage, references to the supernatural, the scientifically inexplicable and the miraculous, and events of science fiction (verses 2, $4,5,15,16,17,18$ of Gil). That field does not appear explicitly in Wonder's lyrics, but can be coherently derived from a key thematic verse in it: "in fact it's just an ordinary day" (which is rendered nearly literally by Gil in the phrase "nenhuma data especial" [no special day]). This new field predominates in Gil's lyrics. It mainly replaces the seasons and their corresponding phenomena (verses 3, 5, 13, 15, 16 by Wonder), but also covers numerically part of the field of holidays, which is mentioned fewer times in Gil's lyrics (3 in Gil's and 6 in Wonder's). 
Contrary to what happens in the case of the new field of Brazilian holidays, the added field of extraordinary things is not typical of the target culture, but is general of a globalized culture (related to contemporary mass media, especially cinema, press and television). Mentions of extraordinary or fantastic phenomena usually explored by science fiction on cinema and television - and which, in that sense, are in the borderline between science, mysticism and arts - are not uncommon in Gil's compositions. Here they could have been inspired by Wonder's verse 17 - "no Libra sun" - that evokes astrology, perhaps the most popular kind of pseudo-scientific mysticism of globalized western culture, and closely linked to mass media.

The whole structure composed by parallelisms, metres and rhymes could be seen as a single broad unit similar to the network functional unit proposed by Nord (1998). The treatment of the semantic fields and their chronological ordering by Gil could be associated not only with Nord's functional units but also with the isotopic chains that Snell-Hornby $(1988 / 1999: 105,103)$ considers in her translation-driven textual analysis. If we look at both lyrics from the point of view of the structural networks in their macro levels, there is a very high density of features transferred from Wonder's lyrics to Gil's. Nevertheless, when considered in a more atomized way, in the micro levels of the sequential surface meanings in corresponding verses, the two lyrics showed so little correspondence between each other...

Gil's adaptation points out the importance of also taking into account, when analysing popular lyric song translations, the parameters of phonetic equivalence, isotopic chains, functional units, the poles of domesticating/foreignizing (see Baker 1998/2005: 127, Venuti 1995) and of adequacy/acceptability (Toury 1978/2000). Such parameters are quite useful in understanding Gil's translation procedures as well as some reasons behind his manipulation of meanings. To ignore these tools would lead us to overlook a careful work of transference done in high and abstract textual levels or in extremely low levels (language sounds).

\section{Digestion under the sign of invention: possible influences on Gil's intercultural attitude}

In his song translation, Gil seems to claim the role of a co-author and the authority to interpret and (re)formulate according to his reading of what is essential or secondary in the original text, but he maintains very close proximity to Wonder's lyrics close enough that we may recognize an identity of message, of imagery and structure, important similarities between patterns of cohesion and coherence, identities that characterize the lyrics in Portuguese as a translation-transcreation of the American ones, and not simply the result of an appropriation of tune as a pretext for lyrics that are fundamentally different.

The pair Halloween/Carnival illustrates the option that Gil makes to deal with the distances between the cultural systems at play in this translation: a cultural adaptation that is based on intersections, identities and analogies between the two cultures. He does not seem interested in focusing on the other culture's alterity, represented by Halloween or by the holidays that are meaningful to Americans, in order to introduce them to the cultural universe of Brazilians. His translation appears to seek an underlying identity between the different forms of cultural expression, perhaps suggested by a supposedly universal theme - or at least one that is among 
the most familiar and common in the popular songs of any culture, namely, love. The sought effect is one of domestication/naturalness, and hence Carnival appears as a Brazilian correspondence of Halloween.

Gil's translation evinces a succession of choices motivated by the source lyrics, but driven towards the pole of acceptability, prioritizing the norms of the target culture and conforming to the requirements of (1) recreation in translation of poetry; (2) the demands of a constrained translation (matching the tune, in this case); (3) the characteristics of popular song reception; and (4) coherence with his own repertoire.

It is worth noting the links that tropicalists such as Caetano Veloso and Gil had with transcreators and concrete poets such as the Campos brothers (see Calado 1997: 180, 183). For Haroldo de Campos, inspired by Jakobson's ideas, "the rank of impossibility is part of the very nature of poetry translation" (Campos 1969b: 121, our translation), and thus, in the case of poetry, it is only possible to "translate under the sign of invention" (Campos 1969b: 111, our translation). In a translation of poetry, it is like "tearing down the machine of creation and assembling it anew" (Campos 1962/1992: 43, our translation), and in this sense, translation is an act of criticism, and "translating is the most attentive mode of reading" (Campos 1962/1992: 43, our translation). In the translation of poetry, the source text needs to be creatively reconfigured:

In a product that is only unfaithful to the textual meaning in order to be inventive, and is inventive inasmuch as it deliberately transcends the faithfulness to the meaning to achieve greater loyalty to the spirit of the transferred original text and to the aesthetic sign itself, considered as a total entity, indivisible both in terms of its material reality (in its physical support, which should often be placed on the front burner of the translator's concerns) as well as in its conceptual content (Haroldo de Campos 1962/1992: 47, our translation).

It is necessary to be inventive to transcend the meaning in order to be loyal to some kind of "spirit," and, therefore,

[i]n the translation of a poem the essential thing is not the reconstitution of the message, but the reconstitution of the system of signs in which this message is incorporated, the reconstitution of the aesthetic information, not the merely semantic information. This is why Walter Benjamin holds that a bad translation (of a work of verbal art) is characterized by being the simple transmission of the message of the original, that is, "the inexact transmission of an inessential content" (Haroldo de Campos 1969a: 100, our translation).

The principles underlying the procedures used by Gil in the translation of the song by Wonder are in perfect keeping with the principles set forth by Haroldo de Campos for the translation of a work of verbal art (see, for instance, Campos 1962/1992; $1969 \mathrm{a}, \mathrm{b}$ and c; 1982/1992), and it is unlikely that this is just a mere coincidence.

The idea that alterity and foreignness fuel the creative drive and help to reinvent identity is present in Gil's career since its beginnings, and has great importance in the avant-garde Brazilian Popular Music movement of Tropicália (see Calado 1997), between 1967 and 1968:

The tropicalists [...] Veloso, Gil, [Tom] Zé and Gal [...] [i]n the beginning of 1967, [...] felt suffocated by the elitist behavior and nationalist prejudice that ruled over the BPM 
domain. [...] they decided that, in order to freshen up the music of Brazil, the only way out would be to promote the taste for Brazilian music among the youth, who showed an ever growing interest in pop and rock of the Beatles and Roberto Carlos. [They claimed] that Brazilian music needed a more universal appeal [...] (Calado 2000).

The ex-tropicalist leaders Gil and Caetano Veloso recognized they were influenced, (through the concrete poets of São Paulo), by the Oswaldian cannibalistic proposals (1928), which can be summarized as follows:

Accounts and legends of the conquest of the Americas refer to the existence of anthropophagism - cannibalism - among the indigenous groups of certain countries, such as Brazil. [T] he poet Oswald de Andrade used "anthropophagy" to describe the assimilation and digestion of elements of European and American culture by modern artists and intellectuals in Brazil (Fundación Cisneros 2002).

If they are not connected through a conscious influence to the ideas that move the Provençal and biblical transcreations of Augusto and Haroldo de Campos, Gil's song translations, at least, are connected to them by the common denominator of dealing with translation as criticism, as one of the most sophisticated forms of reading, and by the shared heritage of seeing in someone else's culture, in foreignness, an important fuel for the creative drive.

\section{NOTES}

1. Wonder, Stevie (1984): I just called to say I love you. In: The woman in red [soundtrack]. Motown. 1 CD. Track 4.

2. GIL, Gilberto (1985/1987): Só chamei porque te amo. In: Gilberto Gil em concerto. Warner. 1 LP. Track 7.

3. For a defense of the translation of poetic function as a type of constrained translation, see Cintrão 2006b e 2006a: 231-244.

4. The English translation of the quotations in Portuguese are from the author.

\section{REFERENCES}

BAKer, Mona, ed. (1998/2005): Routledge Encyclopedia of Translation Studies. London: Routledge.

Calado, Carlos (1997): Tropicália: a história de uma revolução musical. São Paulo: Ed. 34.

Calado, Carlos (2000): Tropicalism: New attitude, new music. Visited June $18^{\text {th }}, 2009$, <http:// www.cliquemusic.com.br/en/Styles/Styles.asp?Status=MATERIA\&Nu_Materia=931 $>$.

CAmpos, Haroldo de (1962/1992): Da Tradução como Criação e como Crítica. In: Haroldo de CAmpos, ed. Metalinguagem e outras metas. São Paulo: Perspectiva, 31-48.

Campos, Haroldo de (1969a): A palavra vermelha de Hoelderlin. In: Haroldo de Campos, ed. A arte no horizonte do provável. São Paulo: Perspectiva, 93-107.

CAmpos, Haroldo de (1969b): Píndaro hoje. In: Haroldo de CAmpos, ed. A arte no horizonte do provável. São Paulo: Perspectiva, 109-119.

Campos, Haroldo de (1969c): A quadratura do círculo. In: Haroldo de Campos, ed. A arte no horizonte do provável. São Paulo: Perspectiva, 121-128.

Campos, Haroldo de (1982/1992): Poesia e música. In: Haroldo de Campos, ed. Metalinguagem e outras metas, São Paulo: Perspectiva, 283-288.

Cintrão, Heloísa Pezza (2006a): Colocar lupas, transcriar mapas. Iniciando o desenvolvimento da competência tradutória em níveis básicos de espanhol como língua estrangeira. Unpublished PhD thesis. Universidade de São Paulo. Visited June $18^{\text {th }}$, 2009, <http://www.teses. usp.br/teses/disponiveis/8/8145/tde-08082007-145636/>. 
Cintrão, Heloísa Pezza (2006b): Fidelidad y finalidad en traducción subordinada. In: Estudios de traducción: problemas y perspectivas, Las Palmas de Gran Canaria: Universidad de Las Palmas de Gran Canaria, 593-606 [CD-ROM].

Collins COBUILD Advanced Learner's Dictionary (2003). Glasgow: Harper Collins.

GorléE, Dinda L. (2005): Song and significance. Virtues and vices of vocal translation. Amsterdam: Rodopi.

Golomb, Harai (2005): Music-Linked Translation [MLT] and Mozart's Operas: theoretical, textual and practical perspectives. In: Dinda L. GorléE, ed. Song and significance. Virtues and vices of vocal translation. Amsterdam: Rodopi, 121-161.

HAUPT, Else (1957): Stil - und sprachkundliche Untersuchungen zum deutschen Schlager. Unpubl. $\mathrm{PhD}$ thesis. University of München.

Halliday, Michael A. K. (2000): Towards a theory of good translation. In: Erich STeIner and Colin YALLOP, eds. Exploring translation and multilingual texts: beyond content. Berlin/New York: Mouton de Gruyter, 13-18.

House, Juliane (1977/1981): A model for translation quality assessment. Tübingen: Narr.

Hurtado Albir, Amparo (2001): Traducción y traductología. Madrid: Cátedra.

JaKoBson, Roman (1959/1966): On linguistic aspects of translation. In: Reuben A. Brower, ed. On translation. New York: Oxford University Press, 232-239.

Jakobson, Roman (1960/2001): Lingüística e Poética. In: Lingüística e comunicação. São Paulo: Cultrix, 118-162.

KAINDL, Klaus (2005): The plurisemiotics of pop song translation: words, music, voice and image. In: Dinda L. GorléE, ed. Song and significance. Virtues and vices of vocal translation. Amsterdam: Rodopi, 235-262.

Low, Peter (2005): The pentathlon approach to translating songs. In: Dinda L. GorléE, ed. Song and significance. Virtues and vices of vocal translation. Amsterdam: Rodopi, 185-212.

Low, Peter (2003): Translating poetic songs. An attempt at a functional account of strategies. Target. 15(1): 91-110.

Mayoral, Roberto; Kelly, Dorothy and Gallardo, Natividad (1988): Concept of constrained translation: non-linguistic perspectives of translation. Meta. 33(3): 356-367.

Nord, Christiane (1998): La unidad de traducción en el enfoque funcionalista. Quaderns. Revista de traducció. 1:65-77.

Reiss, Katharina and Vermeer, Hans J. (1984/1996): Fundamentos para una teoría funcional de la traducción. (Translated by Sandra García Reina and Celia Martín de León) Madrid: Akal.

Rennó, Carlos (2003): Gilberto Gil: todas as letras. São Paulo: Companhia das Letras.

SNell-Hornby, Mary (1988/1999): Estudios de traducción: hacia una perspectiva integradora. (Translated by Ana Sofía Ramírez) Salamanca: Almar.

Titford, Christopher (1982): Sub-titling - Constrained Translation. Lebende Sprachen. 27(3): 113-116.

TourY, Gideon (1978/2000): The nature and role of norms in translation. In: Lawrence VenUti, ed. The Translation Studies Reader. London: Routledge, 198-211.

Venuti, Lawrence (1995): The translator's invisibility. London: Routledge.

Worbs, Hans-Christoph (1963): Der Schlager. Bestandsaufnahme - Analyse - Dokumentation. Ein Leitfaden. Bremen: Carl Schünemann. 


\section{APPENDICES}

\section{Appendix 1 - Alignment and back translation}

Asterisks $\left(^{*}\right)$ indicate verses with no surface meaning correspondences. Fragments with similar meaning are underlined. Dotted underlines indicate a tangential coincidence of meaning.

\begin{tabular}{|c|c|c|c|}
\hline & $\begin{array}{l}\text { I just called to say I love you } \\
\text { Stevie Wonder's lyrics }\end{array}$ & $\begin{array}{l}\text { I just called because I love you } \\
\text { Back translation from } \\
\text { Portuguese }\end{array}$ & $\begin{array}{l}\text { Só chamei porque te amo } \\
\text { Gilberto Gil's adaptation }\end{array}$ \\
\hline 1 & $\begin{array}{l}\text { No New Year's Day } \\
\text { to celebrate }\end{array}$ & $\begin{array}{l}\text { It's not Christmas } \\
\text { nor Happy New Year }\end{array}$ & $\begin{array}{l}\text { Não é Natal, } \\
\text { nem Ano-Bom }\end{array}$ \\
\hline 2 & $\begin{array}{l}\text { No chocolate covered }{ }^{*} \\
\text { candy hearts to give away }{ }^{*}\end{array}$ & $\begin{array}{l}\text { No sign in the sky, } \\
\text { no Armageddon }\end{array}$ & $\begin{array}{l}\text { Nenhum sinal no céu, } \\
\text { nenhum Armagedom * }\end{array}$ \\
\hline 3 & $\begin{array}{l}\text { No first of spring, * } \\
\text { no song to sing * }\end{array}$ & $\begin{array}{l}\text { No special * } \\
\text { day / date, }{ }^{*}\end{array}$ & $\begin{array}{l}\text { Nenhuma data * } \\
\text { especial, }{ }^{*}\end{array}$ \\
\hline 4 & $\begin{array}{l}\text { In fact, here's just another }{ }^{*} \\
\text { ordinary day }{ }^{*}\end{array}$ & $\begin{array}{l}\text { No ET playing * } \\
\text { here in my backyard* }\end{array}$ & $\begin{array}{l}\text { Nenhum ET brincando* } \\
\text { aqui no meu quintal * }\end{array}$ \\
\hline 5 & $\begin{array}{l}\text { No April rain, * } \\
\text { no flowers' bloom * }\end{array}$ & $\begin{array}{l}\text { Nothing special, * } \\
\text { nothing bad * }\end{array}$ & $\begin{array}{l}\text { Nada de mais, }{ }^{*} \\
\text { nada de mau * }\end{array}$ \\
\hline 6 & $\begin{array}{l}\text { No wedding Saturday } \\
\text { within the month of June }\end{array}$ & $\begin{array}{l}\text { Nobody with me } \\
\text { apart from loneliness }\end{array}$ & $\begin{array}{l}\text { Ninguém comigo } \\
\text { além da solidão }\end{array}$ \\
\hline 7 & $\begin{array}{l}\text { But what it is } \\
\text { is something true }\end{array}$ & $\begin{array}{l}\text { Not even an original * } \\
\text { verse * }\end{array}$ & $\begin{array}{l}\text { Nem mesmo um verso * } \\
\text { original * }\end{array}$ \\
\hline 8 & $\begin{array}{l}\text { Made up of these three words } \\
\text { that I must say to you }\end{array}$ & $\begin{array}{l}\text { To say to you and } \\
\text { to begin a song }\end{array}$ & $\begin{array}{l}\text { Pra te dizer e } \\
\text { começar uma canção }\end{array}$ \\
\hline 9 & I just called to say I love you & I just called because I love you & Só chamei porque te amo \\
\hline 10 & $\begin{array}{l}\text { I just called } \\
\text { to say how much I care }\end{array}$ & $\begin{array}{l}\text { I just called } \\
\text { because it's big this passion }\end{array}$ & $\begin{array}{l}\text { Só chamei } \\
\text { porque é grande a paixão }\end{array}$ \\
\hline 11 & I just called to say I love you & I just called because I love you & Só chamei porque te amo \\
\hline 12 & $\begin{array}{l}\text { And I mean it } \\
\text { from the bottom of my heart }\end{array}$ & $\begin{array}{l}\text { There in the very bottom, } \\
\text { bottom of my heart }\end{array}$ & $\begin{array}{l}\text { Lá bem fundo, } \\
\text { fundo do meu coração }\end{array}$ \\
\hline 13 & $\begin{array}{l}\text { No summer's high, } \\
\text { no warm July }\end{array}$ & $\begin{array}{l}\text { Neither Carnaval, } \\
\text { nor Saint John's Festival }\end{array}$ & $\begin{array}{l}\text { Nem Carnaval, } \\
\text { nem São João }\end{array}$ \\
\hline 14 & $\begin{array}{l}\text { No harvest moon to light } \\
\text { one tender August night }\end{array}$ & $\begin{array}{l}\text { No balloon in the sky, } \\
\text { neither backwoods' moonlight }\end{array}$ & $\begin{array}{l}\text { Nenhum balão no céu, } \\
\text { nem luar do sertão }\end{array}$ \\
\hline 15 & $\begin{array}{l}\text { No autumn breeze, * } \\
\text { no falling leaves * }\end{array}$ & $\begin{array}{l}\text { No photo }{ }^{*} \\
\text { in the newspapers }{ }^{*}\end{array}$ & $\begin{array}{l}\text { Nenhuma foto * } \\
\text { no jornal }{ }^{*}\end{array}$ \\
\hline 16 & $\begin{array}{l}\text { Not even time for birds* } \\
\text { to fly to southern skies * }\end{array}$ & $\begin{array}{l}\text { No appearance* } \\
\text { in the gossip column * }\end{array}$ & $\begin{array}{l}\text { Nenhuma nota } \\
\text { na coluna social }\end{array}$ \\
\hline 17 & $\begin{array}{l}\text { No Libra sun, } \\
\text { no Halloween }\end{array}$ & $\begin{array}{l}\text { No mummy } \\
\text { moved }\end{array}$ & $\begin{array}{l}\text { Nenhuma múmia } \\
\text { se mexeu }\end{array}$ \\
\hline 18 & $\begin{array}{l}\text { No giving thanks for all } \\
\text { the Christmas joy you bring }\end{array}$ & $\begin{array}{l}\text { No miracle } \\
\text { of science happened }\end{array}$ & $\begin{array}{l}\text { Nenhum milagre } \\
\text { da ciência aconteceu }\end{array}$ \\
\hline 19 & $\begin{array}{l}\text { But what it is, } \\
\text { tho' old, so new }\end{array}$ & $\begin{array}{l}\text { No cause, } \\
\text { neither reason * }\end{array}$ & $\begin{array}{l}\text { Nenhum motivo, * } \\
\text { nem razão * }\end{array}$ \\
\hline 20 & $\begin{array}{l}\text { To fill your heart like * } \\
\text { no three words could ever do * }\end{array}$ & $\begin{array}{l}\text { When nostalgia comes } \\
\text { there isn't explanation * }\end{array}$ & $\begin{array}{l}\text { Quando a saudade vem * } \\
\text { não tem explicação * }\end{array}$ \\
\hline
\end{tabular}




\section{Appendix 2 - Semantic fields in Stevie Wonder's lyrics}

Implicit reference to festivals (second column) and indirect references to months (third column) are in brackets.

\begin{tabular}{|c|c|c|c|c|}
\hline & Festivals & $\begin{array}{l}\text { Months and } \\
\text { seasons }\end{array}$ & $\begin{array}{l}\text { Natural } \\
\text { phenomena }\end{array}$ & $\begin{array}{l}\text { Contextual/metalinguistic } \\
\text { references }\end{array}$ \\
\hline 1 & $\begin{array}{l}\text { New Years Day } \\
\text { celebrate }\end{array}$ & [January] & & \\
\hline 2 & $\begin{array}{l}\text { chocolate covered } \\
\text { candy hearts } \\
\text { [Valentine's Day] }\end{array}$ & [February] & & \\
\hline 3 & & first of spring & & \\
\hline & & [March] & & no song to sing \\
\hline 4 & & & & $\begin{array}{l}\text { In fact, it's just another } \\
\text { ordinary day }\end{array}$ \\
\hline 5 & & $\begin{array}{l}\text { April } \\
\text { [April, May] }\end{array}$ & $\begin{array}{l}\text { April rain } \\
\text { flowers' bloom }\end{array}$ & \\
\hline 6 & wedding Saturday & June & & \\
\hline 7 & & & & $\begin{array}{l}\text { But what it is } \\
\text { is something true }\end{array}$ \\
\hline 8 & & & & $\begin{array}{l}\text { Made up of these three words } \\
\text { that I must say to you }\end{array}$ \\
\hline 9 & & & & I just called to say I love you \\
\hline 10 & & & & $\begin{array}{l}\text { I just called } \\
\text { to say how much I care }\end{array}$ \\
\hline 11 & & & & I just called to say I love you \\
\hline 12 & & & & $\begin{array}{l}\text { And I mean it } \\
\text { from the bottom of my heart }\end{array}$ \\
\hline 13 & & $\begin{array}{l}\text { summer's high } \\
\text { July }\end{array}$ & warm July & \\
\hline 14 & harvest (moon) & August & $\begin{array}{l}\text { moonlight } \\
\text { tender August night }\end{array}$ & \\
\hline 15 & & $\begin{array}{l}\text { autumn breeze } \\
\text { [September] }\end{array}$ & $\begin{array}{l}\text { autumn breeze, } \\
\text { falling leaves }\end{array}$ & \\
\hline 16 & & & $\begin{array}{l}\text { birds flying } \\
\text { to southern skies }\end{array}$ & \\
\hline 17 & & & Libra sun & \\
\hline 18 & $\begin{array}{l}\text { Halloween } \\
\text { [Thanksgiving] } \\
\text { Christmas }\end{array}$ & $\begin{array}{l}{[\text { October }]} \\
{[\text { November }]} \\
{[\text { December }]}\end{array}$ & & \\
\hline 19 & & & & $\begin{array}{l}\text { But what it is, } \\
\text { tho' old, so new }\end{array}$ \\
\hline 20 & & & & $\begin{array}{l}\text { To fill your heart like } \\
\text { no three words could ever do }\end{array}$ \\
\hline
\end{tabular}




\section{Appendix 3 - Semantic fields in Gilberto Gil's lyrics (using the back translation)}

Implicit reference to festivals (first column) and indirect references to months (second column) are in brackets. Note that the semantic-conceptual field of the seasons is omitted. Dotted underlines in the fifth column indicate intertextual references.

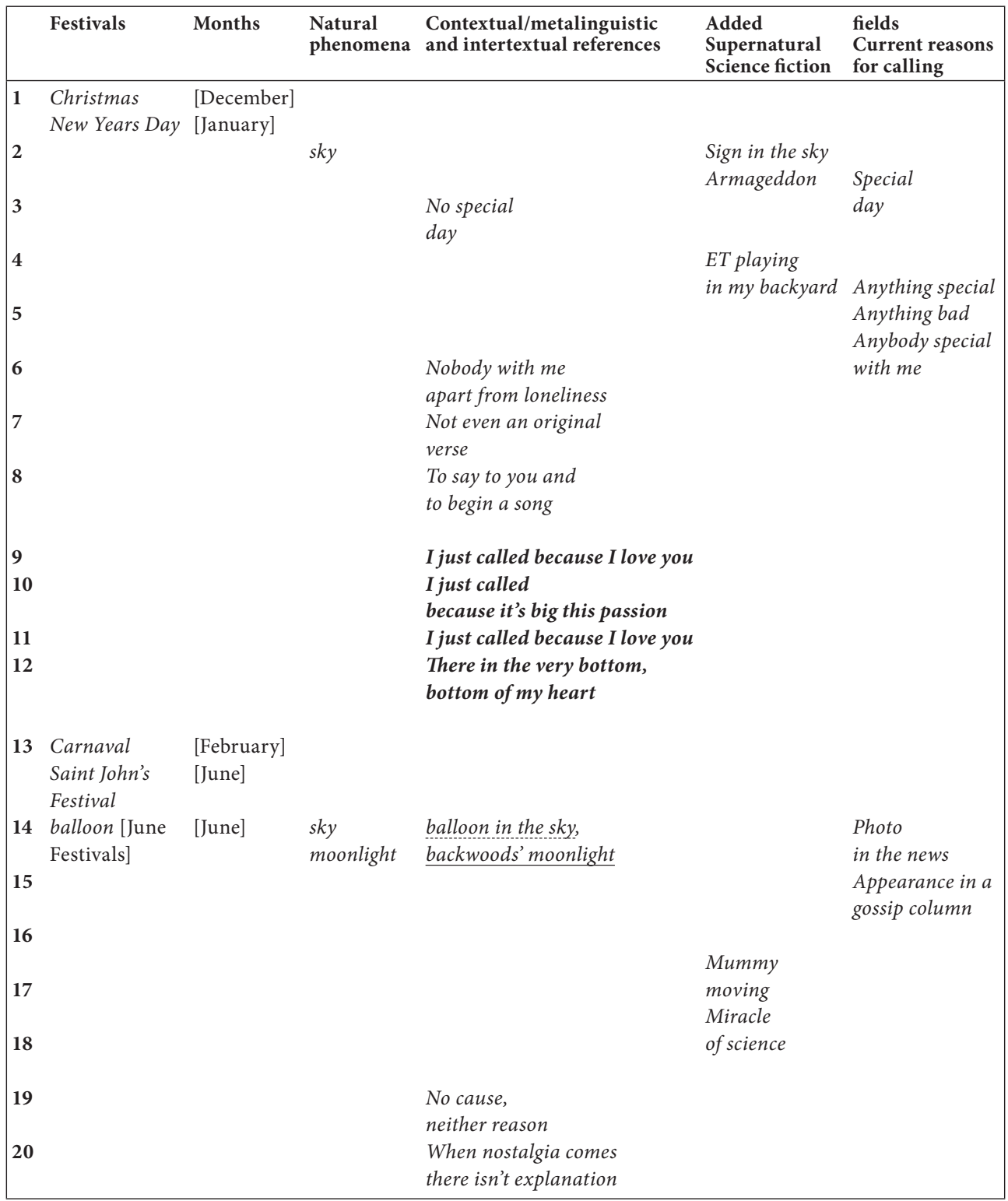

